\title{
The Survival Rate and the Duration of Development in Anomala cuprea HoPE (Coleoptera: Scarabaeidae) under the Thermal Changes along with its Developmental Stage*
}

\author{
Shizuo Fujiyama** and Fumiki Takahashi \\ Entomological Laboratory, College of Agriculture \\ Kyoto University, Kyoto 606, Japan
}

(Received February 10, 1977)

\begin{abstract}
The rearing of Anomala cuprea was conducted under the various programs of thermal change to search for the highest survival rate and the shortest duration of developmental period.

The mortality of 1st and 2nd instar larvae was high under cold temperature lower than $15^{\circ} \mathrm{C}$. From the feeding stage to the yellow stage of 3rd instar larva, the mortality was low at every temperature examined between 15 and $30^{\circ} \mathrm{C}$. During the period from prepupal stage to immature adult, the mortality was low at higher temperatures where they had passed through the low temperature $\left(5^{\circ} \mathrm{C}\right)$ for more than 40 days from the latter period of 2 nd instar to yellow larval stage. In this case the total duration of development was short and its standard deviation was small. The high survival rate during the development was obtained under the changing temperature conditions which were similar to the seasonal change of temperature from summer. Considering these results the most successful program of thermal change to raise this insect was suggested.
\end{abstract}

There are many reports concerned with the effects of daily change of temperature on the development of insects $\left(e . g\right.$. CooK, ${ }^{1)}$ LUdwig, ${ }^{2)}$ HuFfaKer $\left.{ }^{3)}\right)$, but only a few studies have been conducted on the effects of thermal change related to the seasonal change or to the developmental stage of insects (THIELE and KREHAN, ${ }^{4)}$ Thiele, ${ }^{5)}$ Fujiyama and Takahashi. ${ }^{6)}$ Thiele and Krehan ${ }^{4}$ have shown the successful development of larvae of Pterostichus vulgaris is governed by the changing temperature. We reported that the values of the threshold temperature were different among the developmental stages in the cupreous chafer, Anomala cuprea

* Contribution from the Entomological Laboratory, College of Agriculture, Kyoto University, No. 455. This study was supported in part by the grant in aid for scientific research from the Japanese Ministry of Education. A part of this paper was presented at the annual meeting of the Japanese Society of Environmental Control in Biology, Kyoto, Nov. 3, 1973.

** Present address: Department of Biology, Faculty of Science, Shinshu University, Matsumoto 390, Japan.

*** The 3rd instar is discriminated into two stages, "the feeding stage" and "the yellow stage." In the feeding stage the larvae are immature and are light or yellow brown in their body color with their gut contents. In the yellow stage they are mature and yellow colored without any contents in their gut. 
(Fujiyama and TAKAhashi ${ }^{7}$ ). The mortality was higher at lower temperatures in the egg and the 1st instar larval stages while it was higher at higher temperatures in the stages from yellow larva in the 3rd instar*** to immature adult. We also reported that the larval diapause in the yellow larval stage in the 3rd instar was facultative one and their exposure to cold temperature was necessary to terminate the diapause (Fujryama and TAKahashi ${ }^{6}$ ).

Thus, the change of temperature along with the larval development affect not only on the length of developmental period but also on the survival during the development. The seasonal change of temperature seems to be inevitably needed to regulate the life cycle of the cupreous chafer. We attempted to confirm this assumption by rearing the insect under various thermal combinations during the developmental stages. We also suggested the most successful program of thermal change to raise the insect with the highest survival and the minimum length of developmental period.

\section{MATERIALS AND METHODS}

Experiments A-L were set up by the 1st instar larvae hatched from eggs in the laboratory. The eggs were deposited by the adults collected at Hamakita City, Shizuoka Pref. in 1971 and 1972. The larvae used at the start of experiments M-P were collected from a field at Hamakita City in October 1971. These larvae were kept under the field condition at Kyoto University campus until they were used, that is, $\mathrm{M}$ and $\mathrm{O}$ were until the $3 \mathrm{rd}$ of November, and $\mathrm{N}$ and $\mathrm{P}$ were until the 24th of November or the 13th of December. At that time they developed to the feeding stage or the yellow stage in the 3rd instar.

The temperature condition at each developmental stage and the initial number of individuals used were shown in Fig. 1. The rearing methods were the same as in previous papers (Fujiyama and TAKaHASHI ${ }^{6,7)}$ ). Briefly said, they were reared singly in a $150 \mathrm{ml}$ mayonnaise bottle contained boiled saw dust, dried leaves of oak trees, Quercus glauca and a small amount of water. Experiments were con-

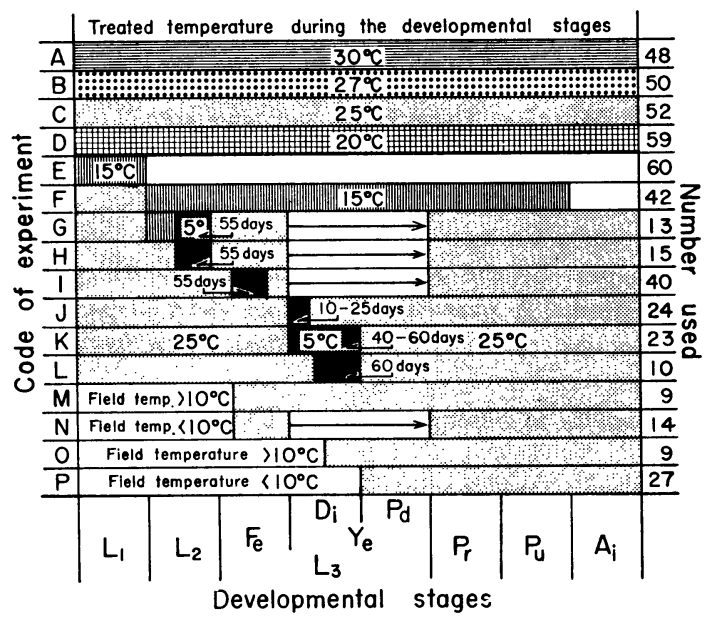

Fig. 1 Rearing condition of temperature in each developmental stage.

$\mathrm{L}_{1}$ : the 1st instar, $\mathrm{L}_{2}$ : the 2nd instar, $\mathrm{L}_{3}$ : the $3 r d$ instar, $\mathrm{F}_{\mathrm{e}}$ : feeding stage in the 3rd instar, $Y_{e}$ : yellow larval stage in the 3 rd instar, $D_{i}$ : diapausing period, $\mathrm{P}_{\mathrm{d}}$ : post-diapausing developmental period in the yellow stage, $\mathrm{P}_{\mathrm{r}}$ : prepupa, $\mathrm{P}_{\mathrm{u}}$ : pupa, $\mathrm{A}_{\mathrm{i}}$ : immature adult. The number in days shows the duration chilled at $5^{\circ} \mathrm{C}$. In experiments G-I and N, major larvae skipped over the diapausing period, which were expressed as blank with an arrow. In $\mathrm{L}$, the chilling was conducted on 150-day-old yellow larvae. The incubations of $\mathrm{M}$ and $\mathrm{O}$ were conducted from the 3rd or November and the incubation of $\mathrm{N}$ and $\mathrm{P}$, from the 24th of November or from the 13th of December. 
ducted at various conditions of constant temperature and $16 \mathrm{~L}-8 \mathrm{D}$ of fluorescent illumination. When the larvae were transferred to the conditions of greatly different temperature in the cases from $25^{\circ} \mathrm{C}$ to $5^{\circ} \mathrm{C}$, from $5^{\circ} \mathrm{C}$ to $25^{\circ} \mathrm{C}$, and from the field condition below $10^{\circ} \mathrm{C}$ to $25^{\circ} \mathrm{C}$, they were passed through the condition of $15^{\circ} \mathrm{C}$ for 3 days to avoid harmful effects by the great shifts of temperature.

\section{RESULTS AND DISCUSSIONS}

\section{The survival}

The survivorship curves from the 1st instar larval stage to the immature adult stage at various temperature conditions are shown in Fig. 2. The results of the mortality in each stage in experiments A-E have already shown partly in a previous paper to examine the period of each developmental stage at various temperatures (FuJIYAMA and TAKAHASHI ${ }^{7)}$ ). In the 1 st instar the mortality was higher at lower temperatures and all the larvae died within this stage at $15^{\circ} \mathrm{C}(\mathrm{E})$. In the 2nd instar the mortality was rather low in every condition such as $34 \%$ even at $15^{\circ} \mathrm{C}$ ( $\mathrm{F}$ and $\mathrm{G}$ ) and this shows a higher tolerance to low temperature in the 2nd instar than in the 1st instar. This coincided with the difference in the threshold temperature of development between the 1 st instar $\left(15^{\circ} \mathrm{C}\right)$ and the 2 nd instar $\left(13^{\circ} \mathrm{C}\right)$. In the $3 \mathrm{rd}$ instar the mortality was low in every case. But many larvae died after the prepupal stage when they were reared further at high constant temperatures (A, B and $\mathrm{C}$ ). While the larvae exposed to $5^{\circ} \mathrm{C}$ for 40 days or more in the period from the latter period of the 2 nd instar to the 3rd instar seldom died thereafter (G-L). It seems that they need a certain duration of exposure to low temperature in these stages for their normal development and this is also related to the fact that the feeding stage in the 3rd instar has the lowest threshold temperature of development $\left(7.5^{\circ} \mathrm{C}\right)$.

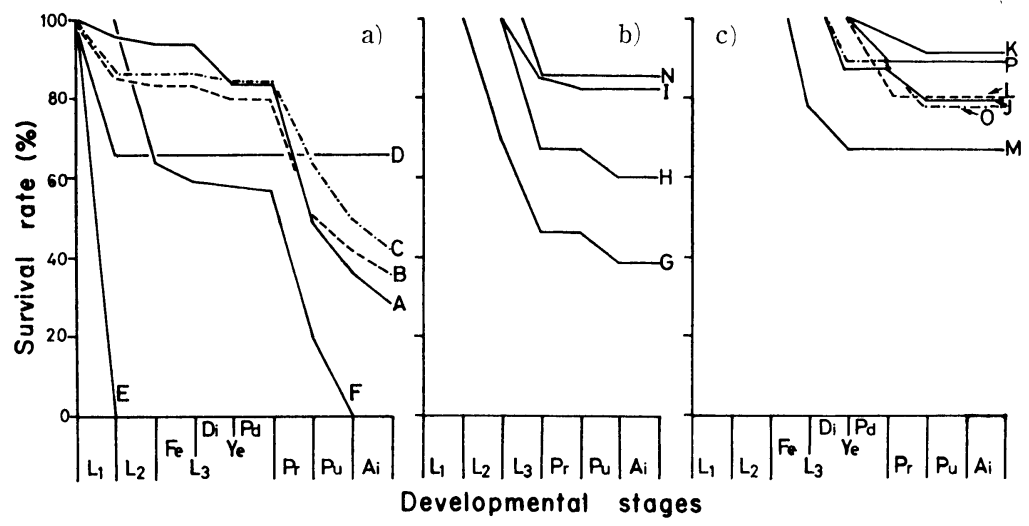

Fig. 2 The effects of various combinations of temperature on the survival rate $\left(l_{x}\right.$-curve) in $A$. cuprea.

The alphabets beside the curves indicate the experimental codes. Symbols of developmental stages refer to Fig. 1. $\mathrm{a}$ : constant temperature conditions, $\mathrm{b}$ : chilling was conducted in the immature larval stage, $\mathrm{c}$ : chilling, in the yellow stage, and other experiments. 
In the prepupal and pupal stages, the mortality was higher at higher temperatures under the constant temperature conditions (A-D) while it was low in the experiments of changing temperature $(\mathrm{G}-\mathrm{P})$, and the high mortality was probably due to the absence of stimulation of low temperature. A cause of high mortality in the pupal stage of $\mathrm{F}$ is not clear, but two possible causes are suspected. One is that the low temperature of $15^{\circ} \mathrm{C}$ was close to the threshold temperature of development $\left(13.9^{\circ} \mathrm{C}\right)$ and greatly retarded the development to result in such a high mortality. Another one is that thermal constancy produced the high mortality since the larvae collected at the field (the underground temperature was below $10^{\circ} \mathrm{C}$ ) in Sakurai City, Nara Pref., prepupated with low mortality $(12 \%)$ at even $15^{\circ} \mathrm{C}$ (Fujryama, unpublished data).

In the immature adult stage the mortality was low when the chilling was conducted in the period from the latter period of the 2nd instar to the yellow larval stage in the $3 \mathrm{rd}$ instar $(\mathrm{G}, \mathrm{H}, \mathrm{I}, \mathrm{J}, \mathrm{K}, \mathrm{L}, \mathrm{N}$, and $\mathrm{P})$. The mortality was also low when the larvae passed a moderate temperature in this period $(\mathrm{D}, \mathrm{M}$, and $\mathrm{O}$ ). But in the constant conditions of higher temperature the mortality was rather high (A, B, and $\mathrm{C}$ ) and all the dead individuals had unexpanded elytra.

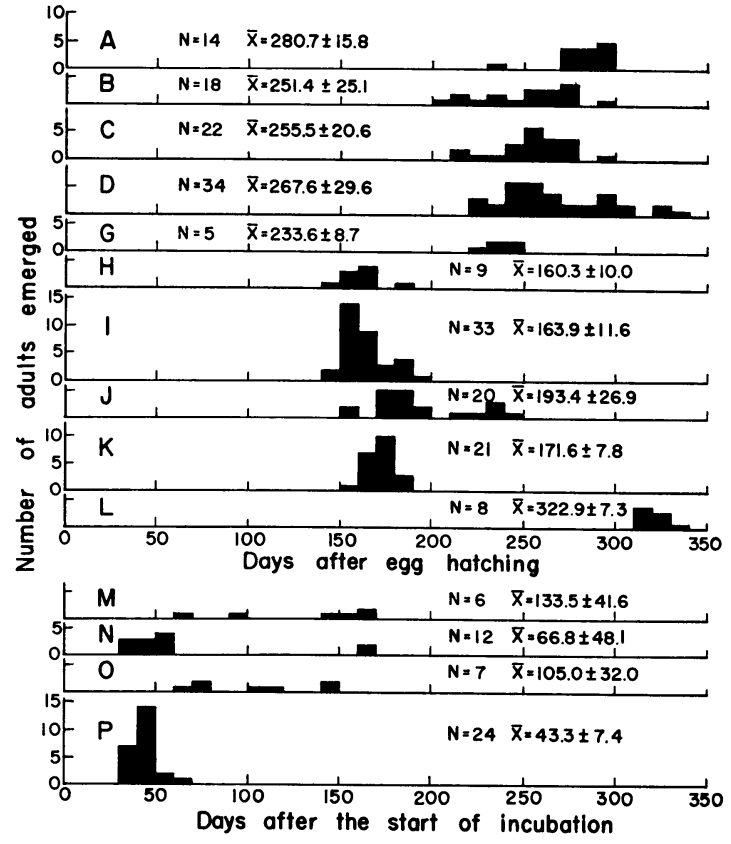

Fig. 3 Frequency distribution of duration from the egg hatching to the adult emergence on to the saw dust in relation to rearing temperature.

The duration in experiments $\mathrm{M}-\mathrm{P}$ is that from the start of incubation. All individuals died before the adult emergence in experiments $\mathrm{E}$ and $\mathrm{F}$ ( $c f$. Fig. 2). $N=$ number emerged, $\bar{X}=$ mean duration \pm S.D. in days.
They scarcely moved and died without emerging on to the saw dust. This death was probably due to the lack of stimulation of low temperature.

\section{The duration of development}

The results are shown in Fig. 3. In the constant temperature conditions (A-D), the mean duration of total developmental period (from the 1st instar larval stage to adult emergence on to the saw dust) was longer than 250 days owing to the diapause in the yellow larval stage as shown in previous papers (FuJIYAma and TAKAHASHI ${ }^{6,7)}$ ). On the other hand, when the larvae were exposed to low temperature within the period from latter period of the 2nd instar to yellow stage in the 3rd instar $(\mathrm{H}-\mathrm{K})$, the duration of total developmental period became short and the value of the standard deviation became small. However, when the chilling period was less than 40 days $(\mathrm{J})$, the duration was a little longer than that in the case of the chilling period being 40 days and more (H, I, and $\mathrm{K})$. The duration of $\mathrm{G}$ became longer than $\mathrm{H}$ for 
about 73 days, because the larvae spent many days under the low temperature of $15^{\circ} \mathrm{C}$ in the 2 nd instar for 84 days, which corresponded to about 14 days at $25^{\circ} \mathrm{C}$ calculated from the law of heat summation (Fujiyama and TAKahashi ${ }^{7)}$ ). In $\mathrm{L}$, larvae had been in diapause for 150 days before the chilling treatment and the total developmental period took more than 300 days. But they developed promptly and uniformly after the treatment. The total period except the diapausing period (150 days) was nearly as same as in $K$. Large values of the standard deviation were observed in the experiments where the larvae were collected in the field ( $\mathrm{M}, \mathrm{N}$, and $\mathrm{O}$ ), and the chilling period seemed to be insufficient to complete their diapause. The large value in $\mathrm{N}$ was due to the extremely retarded development of two individuals as shown in Fig. 3 and the other individuals developed rapidly and uniformly as in the case of $\mathrm{P}$. This showed that almost all larvae in $\mathrm{N}$ had been sufficiently exposed to low temperature to skip over the larval diapause. The yellow larvae in $\mathrm{P}$ had already terminated the diapause by the time of incubation.

The program of rearing temperature to obtain a high survival rate and a rapid development

The range in which a high survival rate will be attained in each developmental stage is estimated from these experiments and is shown in Fig. 4. This shows that the optimum temperature for development is different for each stage. The same result was shown in a melolonthine scarabaeid, Costelytra zealandica by Wightman. ${ }^{8)}$ However, these results indicate that the individuals can take a high survival rate only when they had the appropriate conditions in their past life (Fig. 2). The yellow larvae, even though they were kept at $25^{\circ} \mathrm{C}$, could not prepupate with a high survival rate unless they had exposed to a low temperature condition in the period from latter period of the 2 nd instar to yellow larval stage.

For the purpose of mass-production of $A$. cuprea, the most beneficial alternation of temperature is examined from these experimental results. This rearing program is also shown as R.P. in Fig. 4. This program is determined by adopting the highest velocity for each devel-

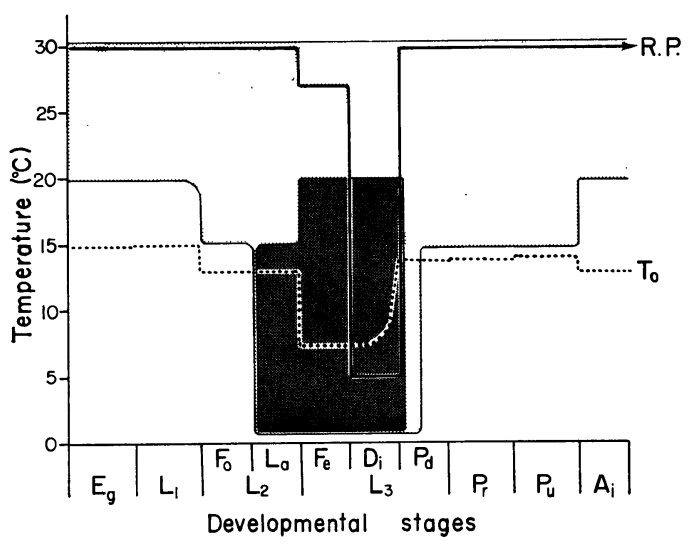

Fig. 4 Temperature range of high survival rate and the rearing program.

The symbols of the developmental stages refer to Fig. 1 and the additional 3 stages are $E_{g}$ : egg, $F_{o}$ : former period of the 2 nd instar, $\mathrm{L}_{\mathrm{a}}$ : latter period of the 2nd instar. The shadowed area shows the range of high survival rate for each stage. The darkly shadowed area indicates the range of low temperature to terminate or skip over the larval diapause with a high survival rate. $T_{0}$ shows the threshold temperature of development. R.P. shows the most beneficial program of temperature alternation for the rearing of $A$. cuprea. 
opmental stage except the yellow larval stage. Furthermore, the most important procedure is to expose the $3 \mathrm{rd}$ instar larvae to low temperature $\left(5^{\circ} \mathrm{C}\right)$ for 50 days because the exposure insures the high survival rate during the period from yellow larval stage to immature adult stage and the smallest standard deviation in total developmental period. The temperature of the highest velocity of development in each stage coincides with the one of the highest survival rate in this case. From this program, the duration of total developmental period is calculated to be about 160 days.

This program is very similar to Wightman's report. ${ }^{8)}$ But there are different programs of rearing for scarabaeid larvae as adopted by $e . g$. HurPin and FRESNEAU, ${ }^{9}$ and Wensler. ${ }^{10)}$ They suggested a constant temperature program, but this difference has not been analysed yet.

We wish to express our grateful thanks to Messers. S. NAKAmURA and H. FURUKI, Shizuoka Pref. for their kind help in collecting materials.

\section{REFERENCES}

1) Cook, W. C. 1927. Some effects of alternating temperatures on the growth and metabolism of cutworm larvae. J. Econ. Entomol. 20: 769-782.

2) Ludwig, D. 1928. The effects of temperature on the development of an insect (Popillia japonica NewmaN). Physiol. Zool. 1: 358-389.

3) HUfFAKER, C. B. 1944. The temperature relations of the immature stages of the malarial mosquito, Anopheles quadrimaculatus SAY, with a comparison of the developmental power of constant and variable temperatures in insect metabolism. Ann. Entomol. Soc. Am. 37: 1-27.

4) Thiele, H. U., and I. KrehaN. 1969. Experimentelle Untersuchungen zur Larvaldiapause des Carabiden Pterostichus vulgaris L. Entomol. Exp. Appl. 12: 67-73.

5) Thiele, H. U. 1969. The control of larval hibernation and of adult aestivation in the carabid beetles Nebria brevicollis F. and Patrobus astrorufus STRoEm. Oecologia 2: 347361.

6) Fujiyama, S., and F. Takahashi. 1973a. Studies on the self-regulation of life cycle in Anomala cuprea HoPE. 2. The effects of low temperature and photoperiod on the induction and termination of the larval diapause. Mem. Coll. Agric. Kyoto Univ. 104: 31-39.

7) Fujiyama, S., and F. TAKAhashi. 1973. Studies on the self-regulation of life cycle in Anomala cuprea HOPE. 1. The effects of constant temperature on the developmental stages. Mem. Coll. Agric. Kyoto Univ. 104: 23-30.

8) Wightman, J. A. 1974. Rearing Costelytra zealandica (Coleoptera: Scarabaeidae). 6. Moisture content and temperature of medium. N.Z.J. Zool. 1: 231-239.

9) Hurpin, B., and M. Fresneau. 1970. Etude en laboratoire du development larvaire de Oryctes monoceros et O. rhinoceros (Col. Scarabaeidae). Ann. Soc. Entomol. Fr. (H.S.) 6: 193-214.

10) Wensler, R. J. 1971. Biology and rearing of the scarabaeid, Sericesthis geminata (Coleoptera). J. Aust. Entomol. Soc. 10: 285-289. 
$<$ 和文抄録 $>$

ドウガネブイブイの生存率と発育期間——特に発育期に結びついた温度変化の効果

\section{藤 山 静雄・高 橋史 樹}

京都大学费学部昆虫学研究窒

ドウガネブイブイを高い生存率かつ短い成長期間で飼育する方法を知るため，いろいろな温度条件の 䊼合せのもとで佂育した。

1 令幼虫は低温 $\left(15^{\circ} \mathrm{C}\right)$ で生存できなかったが，2 令幼虫は低温でも生存率が滈かった。 3 令椇食期 から 3 令黄熟期にかけては, $15 \sim 30^{\circ} \mathrm{C}$ のいずれの温度条件下でも生存率がかなり滈かった。しかし， それまでの全期間を高温のみで飼育した㭶合には，一部 3 令黄熟期に死亡がみられた。前蛹期から成虫 潜土期にかけては，2 令後期から 3 令黄熟期に低温を受けた場合には生存率が高かった。この場合の全 成長期間は短く，その標準偏差も他に比較して小さかった。高い生存率定示す温度範囲は発育期によっ て異なっていたが，その変化は夏を出発点と考元た場合の温度の季節変化とよく似ていた。

これらの結果から，温度に関する本種の最も適当な飼育計画を立案した。 